\title{
Technè
}

La science au service de l'histoire de l'art et de la préservation des biens culturels

48 | 2019

Les couleurs de l'Antique

\section{"Reconstruction" of the polychromy of ancient sculpture: a necessary evil?}

La « restitution » de la polychromie des sculptures antiques, un mal nécessaire?

\section{Jan Stubbe Østergaard}

\section{(2) OpenEdition}

\section{Journals}

Electronic version

URL: https://journals.openedition.org/techne/2656

DOI: 10.4000/techne.2656

ISSN: 2534-5168

\section{Publisher}

C2RMF

Printed version

Date of publication: 31 December 2019

Number of pages: 110-119

ISBN: 978-2-11-152831-4

ISSN: $1254-7867$

\section{Electronic reference}

Jan Stubbe Østergaard, "'Reconstruction" of the polychromy of ancient sculpture: a necessary evil?", Technè [Online], 48 | 2019, Online since 01 July 2021, connection on 02 April 2022. URL: http:// journals.openedition.org/techne/2656 ; DOI: https://doi.org/10.4000/techne.2656

La revue Technè. La science au service de l'histoire de l'art et de la préservation des biens culturels est mise à disposition selon les termes de la Licence Creative Commons Attribution - Pas d'Utilisation Commerciale - Pas de Modification 4.0 International. 


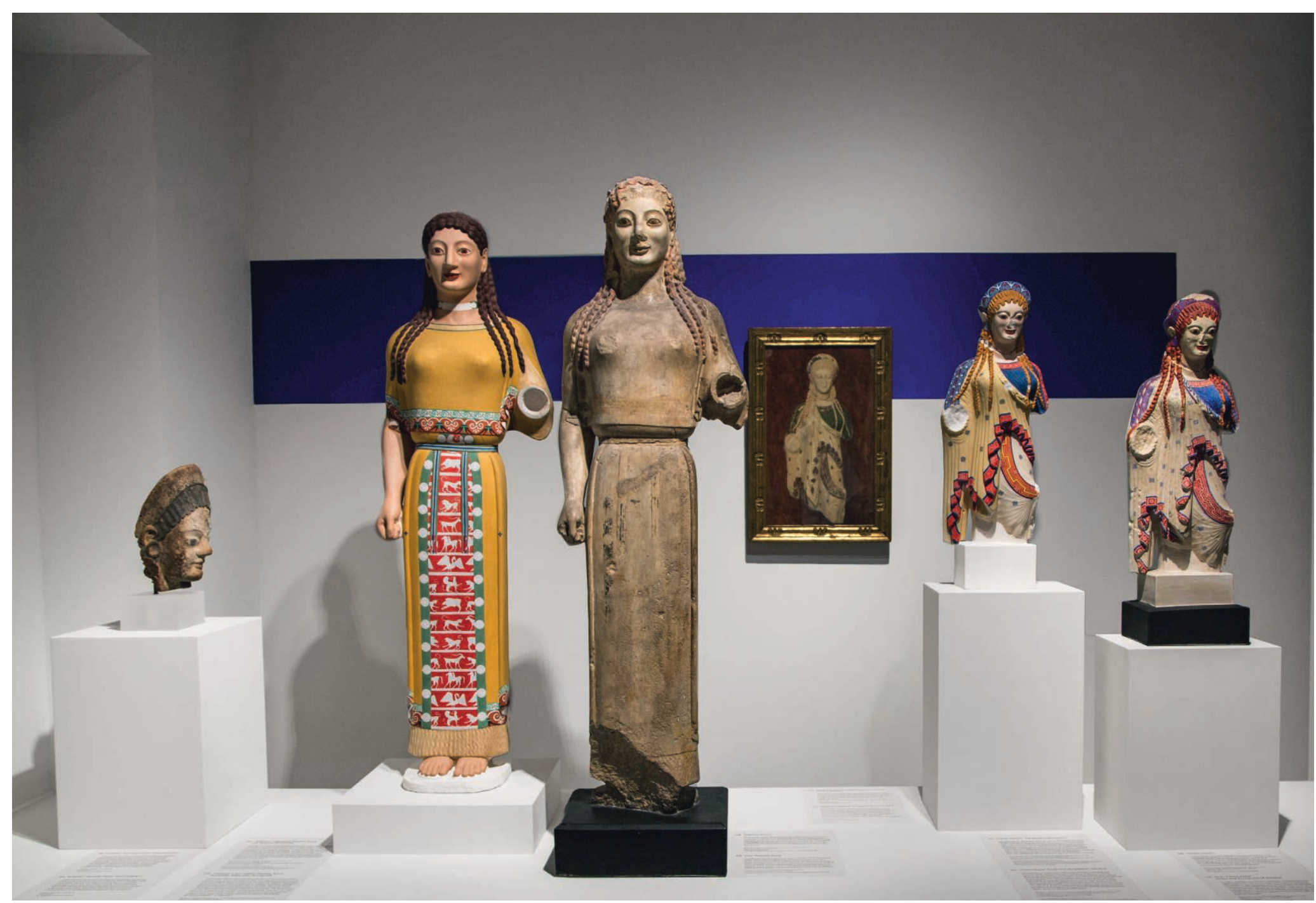

Fig. 1. From the exhibition "Transformations. Classical sculpture in colour", Ny Carlsberg Glyptotek, 2014 () Ny Carlsberg Glyptotek/A.C. Gonzales. 
Jan Stubbe Østergaard

\section{"Reconstruction" of the polychromy of ancient sculpture: a necessary evil?}

La « restitution » de la polychromie des sculptures antiques, un mal nécessaire?

Abstract. The contribution offers an overview of the history of reconstructions and their use, with a representative selection of formats and their contexts, from the beginnings in the early 19th century to the present. The polychromy of ancient architecture is dealt with only to a limited degree.

The point of departure is a perceived need of establishing an informed and critical discussion of the whys and wherefores of reconstructions. On the background of the investigative technologies which have been developed with unprecedented rapidity, a methodological protocol allowing cross-checks of data is recommended.

Keywords. Polychromy, colours, painting, Greek and Roman sculpture, reconstructions, experimental archaeology, 2D, 3D.
Résumé. Cet article présente un bref historique des restitutions et de leur utilisation, avec un choix représentatif des méthodes et de leurs contextes, depuis les prémices au début du XIX ${ }^{e}$ siècle jusqu'à aujourd'hui. Il examine dans une certaine mesure la polychromie des architectures antiques. Le point de départ était la nécessité d'instaurer un débat sérieux et critique sur les fins et les moyens de la restitution. À une époque où les techniques d'investigation se développent avec une rapidité sans précédent, il est recommandé d'adopter un protocole prévoyant un recoupement des données.

Mots-clés. Polychromie, couleurs, peinture, sculpture grecque et romaine, restitution, archéologie expérimentale, 2D, 3D.

\section{Reconstructions: recent appearances and reactions}

Since the late 20th century, considerable resources have been spent on producing reconstructions of ancient sculptural polychromy ${ }^{1}$. This reflects two basic facts: on the one hand, increased research activity and thus a greater amount of available data. On the other hand, the wish to explore the two overarching aspects of reconstructions, namely their usefulness as research tools and as a means of communication to a wider public.

Reconstructions of polychromy on physical, 1:1 copies of the original sculptures have been given a particularly prominent position, both in the public eye and in a scholarly context. Since 2003, such reconstructions have been shown in exhibitions on ancient sculptural polychromy and reproduced in the accompanying catalogues. One such was "Transformations. Colour in classical sculpture" shown at the Ny Carlsberg Glyptotek in 2014 (fig. 1), but the most important has been the exhibition "Bunte Götter. Die Farbigkeit antiker Skulptur". Having been presented in more than twenty different venues, it has been seen by an estimated three million visitors ${ }^{2}$.
In the scholarly community, there is however disagreement as to the validity - or even acceptability - of these objects, be they called "reconstructions", "approximations", "experimental archaeological projects", "research experiments", or "didactic (cognitive) objects on the basis of scientific research"3.

The criticisms voiced and the arguments countering them have hitherto very largely been expressed verbally, in discussions at earlier Round Tables and at other meetings on polychromy. The impression gained from these discussions and what I have been able to find in publications is expressed in the subtitle of this paper.

The aim of the present article is to contribute in a nonpartisan manner to a constructive dialogue on the problems connected with reconstructions and their use by offering a brief overview of the history of reconstructions, attempting to include a representative range of media formats employed, and their contexts. 


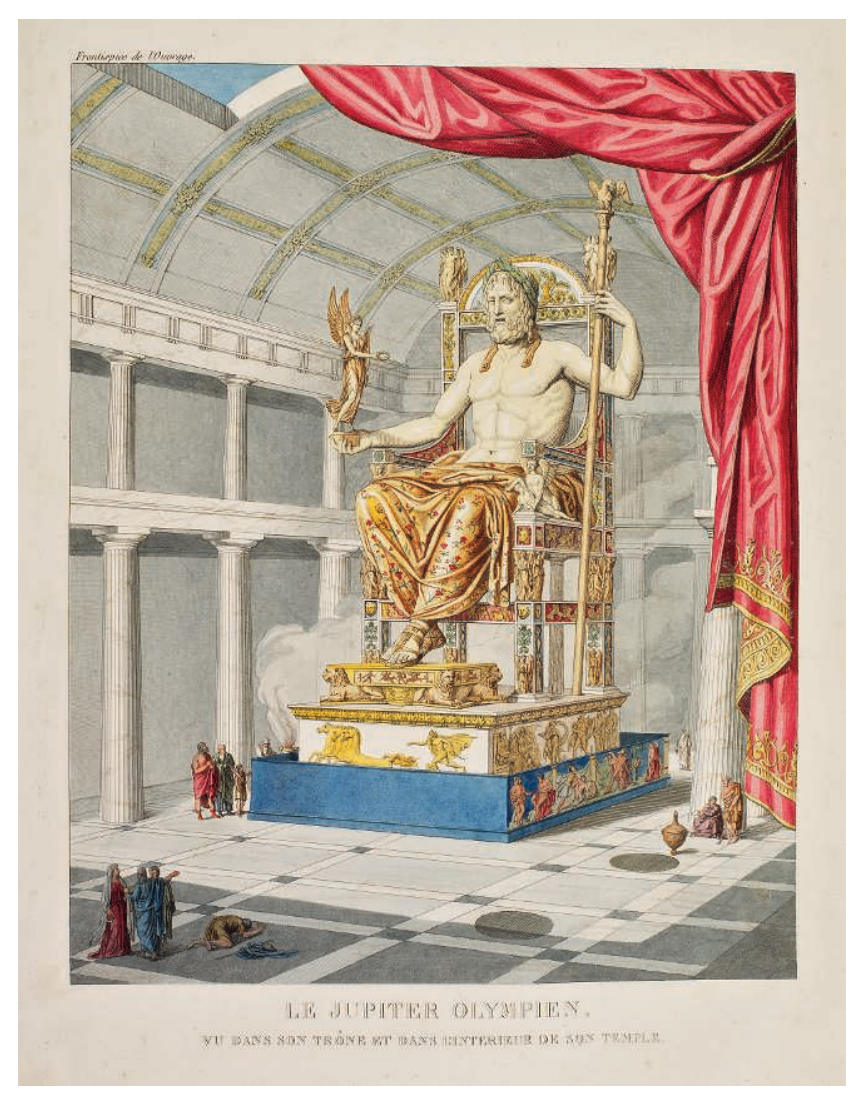

Fig. 2. Reconstruction of the chryselephantine cult statue of Zeus in the Temple of Zeus at Olympia, colour lithograph, frontispiece of A.-C. Quatremère de Quincy, 1814, Bibliothèque de l'INHA, collections Jacques Doucet. Open Licence.

\section{The two-dimensional format: Le Jupiter olympien, 1814}

Reconstruction of the polychromy of ancient sculpture has a history going back to the early 19 th century. With the addition of digital imaging technologies, the media employed during that century are all still in use. A complete overview of 19th century "approximations" is of course not possible 4 . My aim is to strike some key notes.

The term "approximation" is one used by the pioneer in polychromy studies, Antoine-Chrysostome Quatremère de Quincy (1755-1849) in his ground-breaking work Le Jupiter olympien from $1814^{5}$. His brilliant "Avant-propos" is far ahead of its time in its lucid dealing with the issue of reconstructions. He uses a range of terms: "restitution", "restitution approximative" and "image approximative", a term for which "Annäherungen" is the word later used by German authors. Quatremère's "restitutions” are, he says “... made more out of consideration for the light they might throw on the category of art I wanted to make known, rather than with a view to reproducing the monuments for their own sake" ${ }^{6}$. He hopes that no one thinks that he presumes to show what Phidias' masterpiece looked like (fig. 2) ${ }^{7}$; this colour lithograph is the earliest of a long line of two-dimensional reconstructions on paper in the context of a scholarly publication. Though the format was used on several occasions during the 19th century ${ }^{8}$, a real scholarly advance was only made in the early 20th century when Adolf Furtwängler published reconstructions of the polychromy of the pediments in his publication of his excavations at the temple of Athena Aphaia ${ }^{9}$. It is worth noting that, in the latter 19 th century, this format was also used for publications in colour of selected Greek terracotta statuettes and of the important traces of polychromy preserved on the sculptures excavated on the Acropolis of Athens. This documentation served, and serves, as an important point of reference for reconstructions ${ }^{10}$.

\section{Reconstruction on plaster casts: The Greek Court in The Crystal Palace, 1854}

The building erected in Hyde Park in London for the international "Great Exhibition" in 1851 and nicknamed "The Crystal Palace" was subsequently re-erected in Sydenham in South London. The huge structure reopened in 1854 and between 1854 and 1874, 34 million entrance tickets were sold: The Palace may safely be said to have had a mass audience. Among the showpieces were a series of historical "courts", one of them Greek. The Greek Court featured reconstructions of the polychromy of elements of the architecture of the Parthenon and plaster casts of a section of the Parthenon frieze. The reconstructed polychromy was due to the architect Owen Jones who published a booklet entitled "An Apology for the Colouring of the Greek Court" 11 . Jones presented archaeological, philological and epigraphical evidence for the polychromy and included a survey by Gottfried Semper, an international protagonist of the on-going debate on polychromy in ancient sculpture and architecture. The publication was a highly qualified reply to the strong criticism voiced and offers the first summary in English of the evidence for polychromy. Owen Jones does not use the word "reconstruction". Instead he usefully introduces

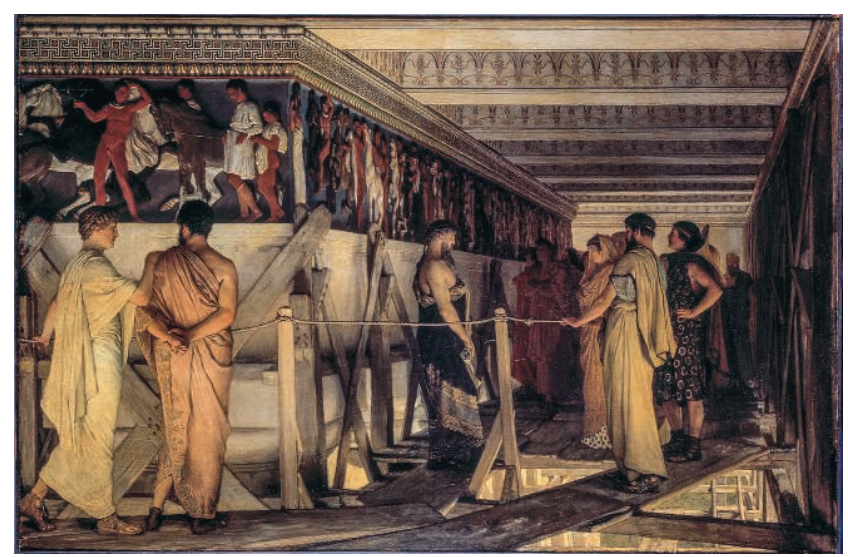

Fig. 3. Sir Lawrence Alma-Tadema (1836-1912), Phidias showing the frieze of the Parthenon to his friends (1868-1869), oil painting on mahogany board $(72 \times 110.5 \mathrm{~cm})$, Birmingham Museum and Art Gallery, inv. 1923P118. Courtesy of Birmingham Museum and Art Gallery. 
"experiment" and "attempt" - and states that he hopes to "induce further researches on the monuments of Greece..."12. From this first instance on, physical reconstruction of polychromy on casts of the original, in the context of an exhibition as well as in more permanent installations, is a format that has been with us since.

We have only black-and-white photographs of the "coloured" frieze in the Greek Court, but in her 2015 book Greece and Rome at the Crystal Palace. Classical Sculpture and Modern Britain, 1854-1936, Kate Nichols opens the possibility that we do in fact have a colour rendering of the reconstruction in the famous painting from 1868 by Sir Lawrence Alma-Tadema (1836-1912), "Phidias Showing the Frieze of the Parthenon to his Friends". The polychromy of the frieze may perhaps be inspired by the visit Alma-Tadema paid to The Palace in $1862^{13}$ (fig. 3).

\section{Scale model reconstructions: Georg Treu and Adolf Furtwängler}

In 1875, the first systematic "modern" archaeological excavation of a classical site began at the Sanctuary of Zeus at Olympia ${ }^{14}$. Among the protagonists was the classical archaeologist Georg Treu (1843-1921) ${ }^{15}$. He was field director from 1877 until 1881 and intensely involved in reassembling the metope reliefs and pedimental sculptures of the Temple of Zeus. His observations of the numerous traces of polychromy on the sculptures from Olympia were published in $1895^{16}$, and what he had seen inspired him when he was appointed director of the Albertinum in Dresden in 1882. In its collection of casts, the pediments and metopes from Olympia took pride of place. Here, Treu introduced the visitor to the original polychromy by way of a permanently exhibited reconstruction of the east front of the temple in scale 1:10 (fig. 4), thus powerfully demonstrating the symbiotic relationship of architectural and sculptural polychromy. The thinking behind the use of reconstructions was put forward in his famous lecture "Sollen wir unsere Statuen bemalen?", published in $1884^{17}$. The occasion of the lecture was the first ever exhibition on polychromy in ancient and contemporary sculpture, subsequently shown also in the National-Galerie in Berlin, in $1885^{18}$. In his lecture, Treu did not mince his words regarding the reconstructions shown: “... the adventure (i.e. of reconstruction), perilous as it is, must be dared if our ideas of ancient polychromy are not to remain disembodied, theoretical talk ${ }^{19}$."

Twenty years later, Adolf Furtwängler, director of the Glyptothek in Munich, followed Treu's example. A 1:5 scale model of the east front of the temple of Athena Aphaia on Aegina was set up in the gallery displaying the originals ${ }^{20}$. Furtwängler's reconstruction was based on his intimate knowledge of the originals and his own excavations on the site, thoroughly published in 1906, with reproductions of his reconstructions ${ }^{21}$. Much later, in 2003, a reconstruction of the polychromy of a section of the temple west pediment in scale 1:3 was produced for the exhibition "Bunte Götter. Die Farbigkeit antiker Skulptur"22. Physical scale models for

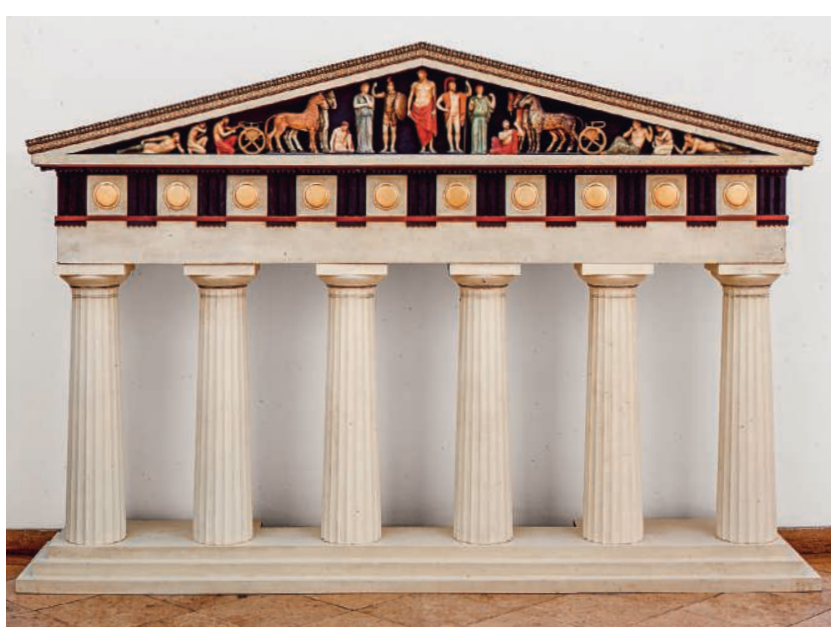

Fig. 4. Reconstruction of the east facade of the Temple of Zeus at Olympia in scale 1:10, 1886, painted by Robert Diez under the direction of Georg Treu, wood, plaster and tempera, Dresden, Albertinum, Abg -ZV 363-02. Courtesy of Staatliche Kunstsammlung, Dresden.

communication of polychromy in architecture to the public has not otherwise flourished; but the digital version of the format is now coming into its own ${ }^{23}$.

\section{Advances in 2D reconstruction and the first 1:1 physical reconstructions}

Furtwängler's observations on polychromy in the1906 publication of his excavations at the Aphaia temple were accompanied by quite spectacular colour lithograph reconstructions of the two pediments ${ }^{24}$, reflecting the leap forward taken by classical archaeology in the second half of the 19th century. The next advance was made in 1944 by Gisela Richter and Lindsley F. $\mathrm{Hall}^{25}$. In connection with Richter's work on Attic Gravestones, the traces of polychromy preserved on Archaic Greek funerary stelai in the Metropolitan Museum of Art were investigated. The results formed the basis of a set of careful colour crayon reconstructions by the artist Lindsley Hall. Their combined publication offered a detailed explanation of the reconstructions. The latter are subdued in comparison to what we now know of the character of Archaic polychromy, but set an example in the methodology of research-based reconstructions. The most recent continuation of this approach is found in Clarissa Blume's 2015 monograph on the polychromy of Hellenistic sculpture (fig. 5) ${ }^{26}$; in her work, she has however in the main not been able to employ the required combination of investigative methodologies ${ }^{27}$.

The example set by Richter was not followed when it came to the first 1:1 physical reconstructions of the polychromy of a Greek sculpture. They were created at the University of Cambridge's Museum of Classical Archaeology, an academic context lending them a special importance. In 1975, the advent of an extra cast of the Late Archaic, Attic "Peplos Kore" allowed a restoration of the statue and a reconstruction of its polychromy using modern pigments under the 


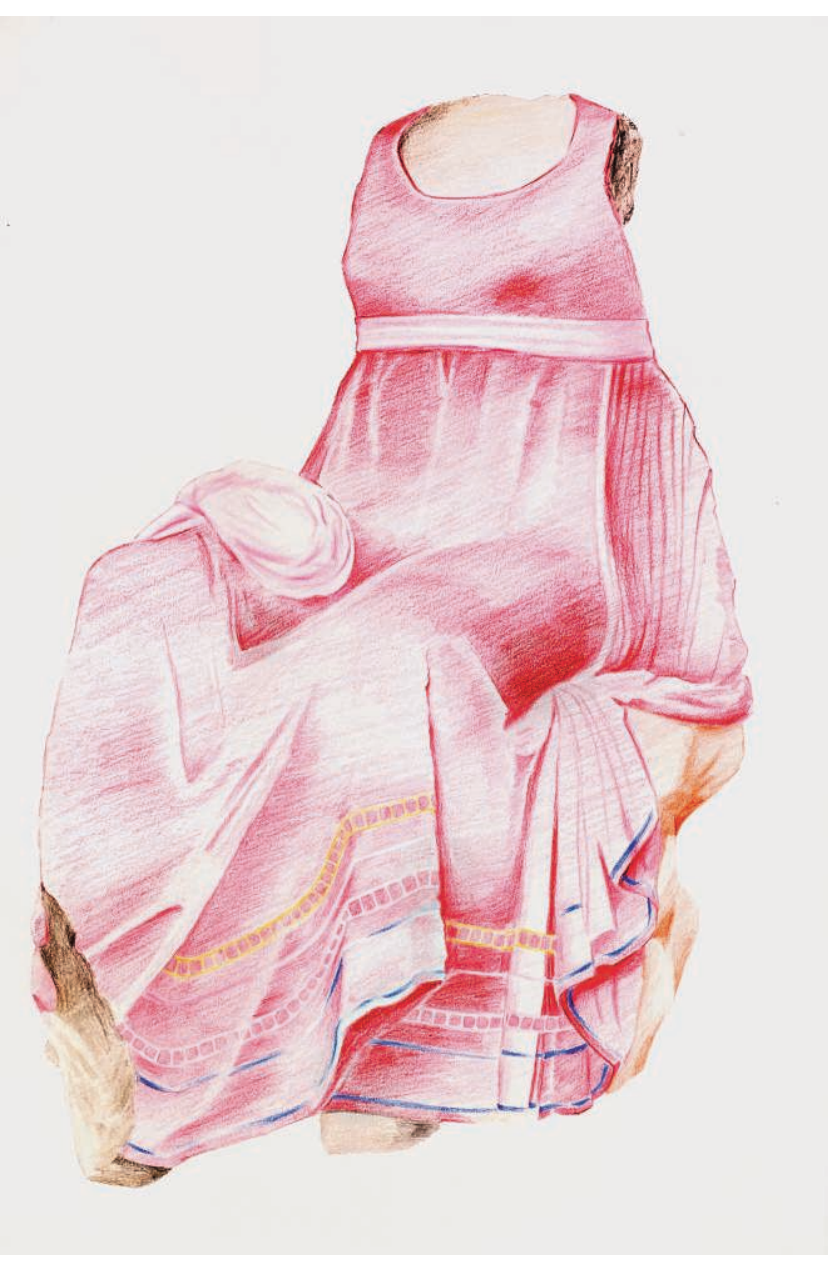

Fig. 5. Reconstruction in colour crayon of the "Seated Muse", Liebieghaus Frankfurt, inv. 163, by Clarissa Blume-Jung (concept) and Erich Strauch (drawing). (C) C. Blume-Jung.

direction of Robert Cook, professor of Classical Archaeology ${ }^{28}$. Probably about the same time, Cook undertook a similar reconstruction of the polychromy of the Early Archaic "Lady of Auxerre"29. The reconstruction of the polychromy of the restored "Peplos Kore" is exhibited next to a cast of the original and is highlighted on the museum's website ${ }^{30}$. The two reconstructions were also reproduced in a two-dimensional format in a contemporary handbook on Archaic Greek sculpture - quite intentionally as black-and-white photographs. Next to them were black-and-white reproductions of reconstructions of other archaic sculptures in the form of painted photographs ${ }^{31}$, a technique which may be seen as a precursor of digital reconstructions using such software as PhotoShop.

\section{6 onwards: A new era of 3D reconstructions}

Returning now to stone sculpture and keeping in mind what has been presented so far, it will be clear that a new era of three-dimensional reconstruction of the polychromy of ancient stone sculpture began in 1986. That year, Raimund Wünsche, director of the Glyptothek in Munich, singled out a head of a warrior from the east pediment of the Temple of Athena Aphaia for a reconstruction of its polychromy, in connection with a TV program sent from the museum. The research basis was due to the then curator Vinzenz Brinkmann's raking light photographic documentation of the weathering reliefs and his ultra-violet fluorescence (UVf) images showing range of greys reflecting the use of several different pigments. The interpretation of this evidence led to the reconstruction of the polychromy. According to Wünsche, its uncertainties were acceptable in the light of the ephemeral character of the TV medium and the need to make the colourful appearance of ancient sculpture clear ${ }^{32}$. The "Warrior Head" has since been a reconstruction test-bed for the range of interpretations allowed by the evidence from the original ${ }^{33}$. Results of further investigation of the "Aeginetans" in Munich by Vinzenz Brinkmann and Ulrike Koch-Brinkmann led to the reconstruction in 1991-1992 of a complete sculpture from the west pediment of the temple, the archer called "Paris". Like the Warrior's Head, the polychromy of "Paris" has also been reconstructed in several versions - reflecting the fundamentally iterative character of polychromy research and giving rise to weighty critical response ${ }^{34}$.

From 2003 onwards, the pioneering reconstruction activities of the team around Vinzenz Brinkmann and Ulrike Koch-Brinkmann gathered new momentum, joined by other institutions. The point of departure was the collaboration between the Staatliche Antikensammlungen und Glyptothek in Munich, the Ny Carlsberg Glyptotek in Copenhagen and the Musei Vaticani in Rome on the first major exhibition on polychromy in ancient sculpture since the late 19th century ${ }^{35}$. Further research and the production of new reconstructions have followed over the years, that of the kore Phrasikleia being especially important ${ }^{36}$. In these German reconstruction projects, a key role has been played by Ulrike KochBrinkmann. Since the 1990s, she has conducted systematic and documented series of trials of natural pigments and binders on marble samples and done tests runs on partial casts of the sculptures to be reconstructed. All this lies at the root of reconstructions such as the Phrasikleia ${ }^{37}$.

\section{The materials of 3D reconstructions: from plaster to synthetic marble and marble}

In connection with the exhibition just mentioned, the traces of polychromy remaining on the portrait statue of Augustus from Prima Porta ${ }^{38}$ were examined and a reconstruction attempted. The research data was published together with the reconstruction - and the project was carried out independently of the Brinkmann and Koch-Brinkmann team ${ }^{39}$. It is of paramount importance to have as many interdisciplinary projects as possible active in research-based experimental reconstruction.

The Augustus reconstruction was made on a plaster cast using the natural pigments identified on the original ${ }^{40}$. A 
plaster cast and natural pigments were also used for the restoration and reconstruction, in connection with the exhibition, of an Archaic Greek lion in the Copenhagen Glyptotek ${ }^{41}$. Plaster has now been largely supplanted by synthetic materials, more expensive but with a surface character closer to that of marble. That marble would be the ideal material to use is as obvious as it is difficult to organize and finance. The first polychromy reconstruction on a marble copy was made in 2003, of the classical Attic funerary stele of Paramythion in the Munich Glyptothek ${ }^{42}$. That year also saw the reconstruction of the portrait of Caligula in the Glyptotek in Copenhagen, though not on the Parian marble of the original, but on largely machine tooled, hand finished marble from Carrara 43 . This Caligula "A" reconstruction was followed by two others, "B" and "C", both in synthetic

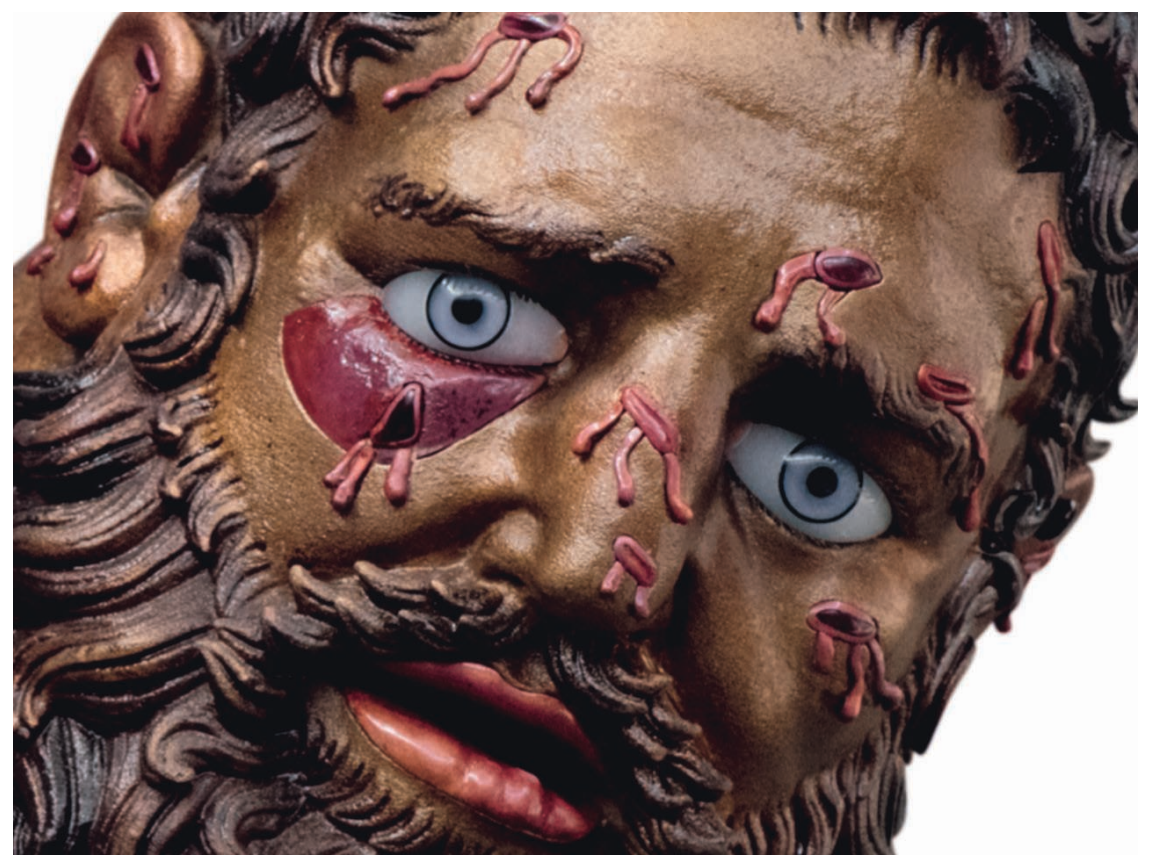

Fig. 6. Reconstruction of the Terme Boxer/Amykos, 2017-2018, detail of head and upper torso. (C) V. Brinkmann/U. Koch-Brinkmann. materials and offering two different interpretations of the data available. In all three, natural pigments were used ${ }^{44}$.

Finally, in 2013-2014, the data obtained from investigation of two replicas of the same portrait type of a Late Severan youth in the Glyptotek formed the basis of a reconstruction on marble, done entirely by hand by a professional sculptor, Matthew Simmonds, and painted by Per Kapper ${ }^{45}$ (fig. 7).

\section{Reconstructing the polychromy of bronze sculpture}

Over the last decades, our ideas of the original appearance of Greek bronze sculpture have changed dramatically. There has been a paradigmatic shift away from the traditional admiration of the patinated surfaces of oxidized bronze, in two phases. The first was brought about by Peter Gercke's 1991 reconstruction of the Kasseler Apollo, most recently shown in Milan in $2015^{46}$. There it stood, in bright bronze and inlays, next to a quite different and more recent version of what classical bronzes might have looked like: the reconstructions of the classical 5th century Greek bronzes from Riace. Here the evidence from scientific investigations has been interpreted as showing a degree of naturalism congruent with that so far found on classical marble sculpture, whether free-standing sculpture in the round or in relief, or in an architectural context ${ }^{47}$. The team formed by Vinzenz Brinkmann has recently presented similar reconstructions of the so-called "Terme Boxer" and the "Terme Ruler"48 (fig. 6). The inherent, mimetic naturalism of the many inlays in a variety of materials is evident, whereas the evidence for the original appearance of the skin surfaces remains inconclusive ${ }^{49}$.

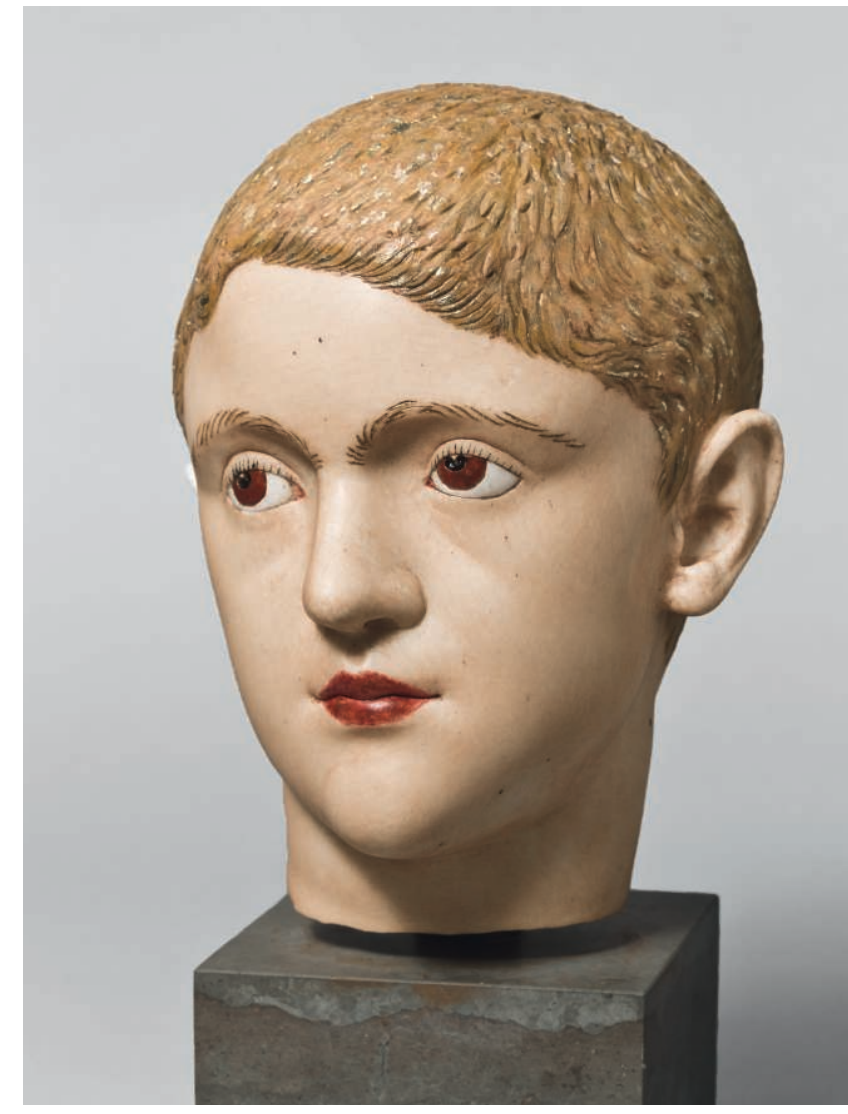

Fig. 7. Reconstruction of the polychromy of a portrait of a Roman youth from $c .230$ in Ny Carlsberg Glyptotek, Copenhagen, inv. 821, by Matthew Simmonds (sculptor) and Per Kapper (painter). (C) Ny Carlsberg Glyptotek/O. Haupt. 


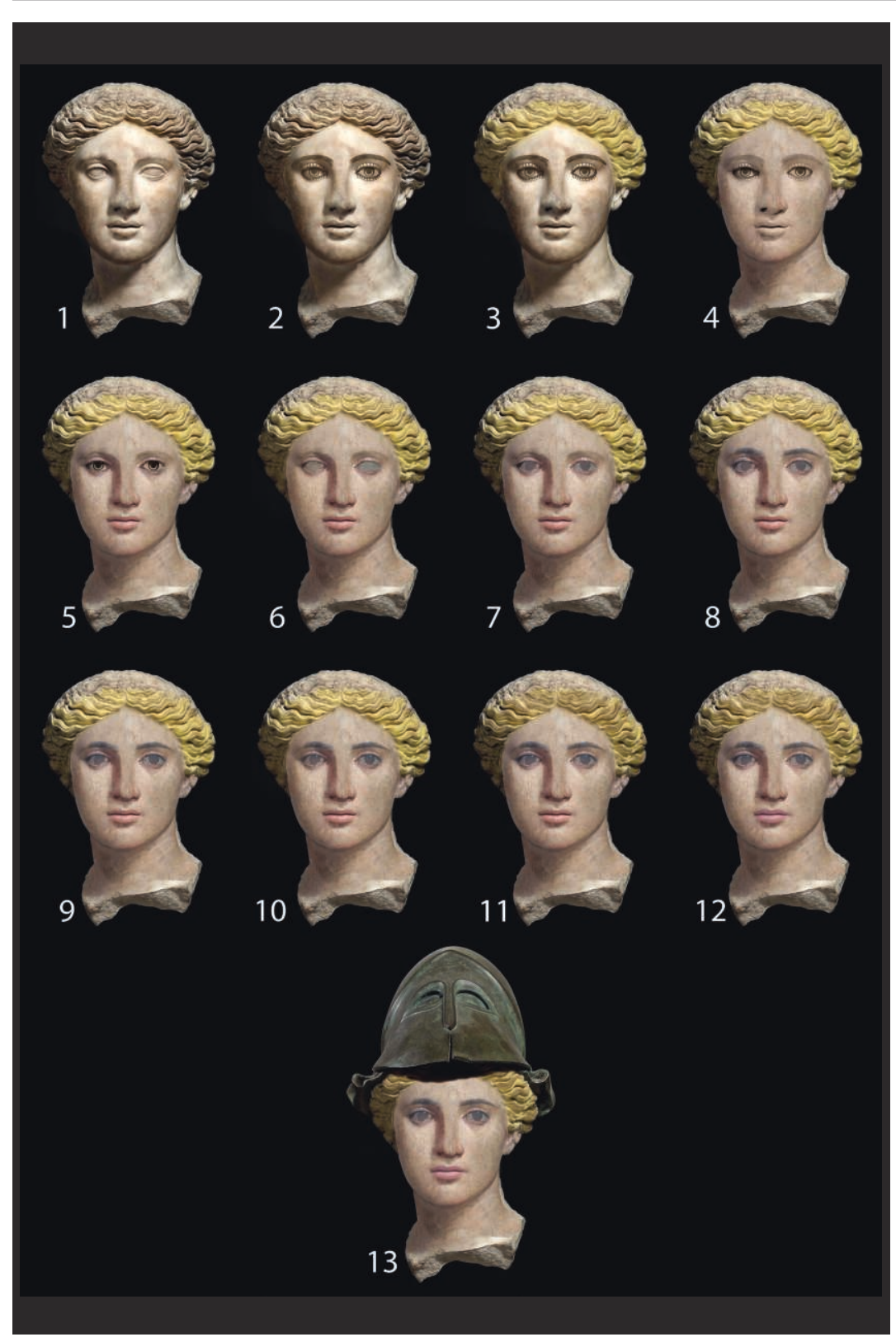

Fig. 8. Digital colour reconstruction of the Treu Head, indicating the sequence in which the head may have been painted in Antiquity. @ G. Verri.

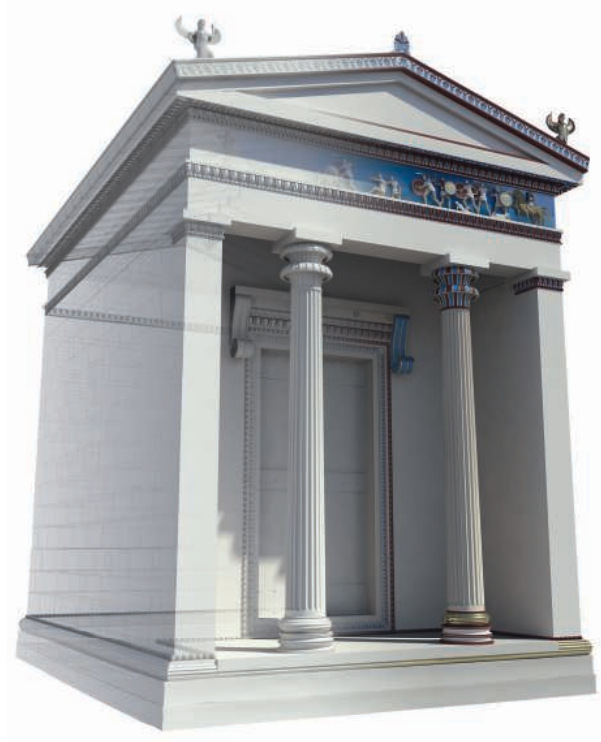

Fig. 9. Digital reconstruction of the Massalian Treasury in Delphi. 3-steps illustration: wireframe, architectural reconstruction and polychrome hypothesis (2013). (C) P. Desbottes, M. Vincitore, L. Gugi (MAP), M. Mulliez.

\section{Developments in 2D analogue and digital reconstructions}

As part of the intricate interpretative process required for reconstructions, Koch-Brinkmann developed the 2D format by producing "draft proposals" in water colour and gouache to clarify proposed reconstructions ${ }^{50}$. This technique is fundamentally like 3D physical reconstructions in being analogue. Both are at one and the same time more authentic than digital techniques in being in close contact with the interaction between eye, painting tool, pigment and object; and then less authentic in being subject to ultimately ahistorical, subjective choices. In 2012, awareness of this potential phenomenological pitfall led conservation scientist Giovanni
Verri to suggest an important digital 2D reconstruction alternative. He transplanted surfaces from contemporary ancient works with a better preserved polychromy to the object under reconstruction; thus, in the case study, from so-called Fayumportrait paintings to the so-called "Treu Head" in the British Museum (fig. 8); it is important to note that his selection of comparanda was based on thoroughly cross-checked imaging and analytical data ${ }^{51}$.

Use is also increasingly being made of ever more refined software to produce 2D digital reconstructions of the polychromy of individual sculptures ${ }^{52}$ or of sculptures in their original context, including lighting conditions ${ }^{53}$. In the reconstruction of the polychromy of large-scale architectural contexts, digital technologies are simply the only way forward; relatively recent work on the Treasury of Massilia at Delphi is 
a qualified case in point (fig. 9) ${ }^{54}$. The temptation to cast off any connection with archaeological evidence has however already manifested itself ${ }^{55}$. It is a field in explosive development which must be discussed on a future occasion.

\section{Conclusions}

Would it be fair to say that reconstructions of polychromy are necessary? In my opinion, yes. Without them, our field would be deprived of a most powerful means of creating a positive public awareness of the presence of colour in ancient sculpture and the concomitant willingness to support research. From the point of view of scholars and specialist, the whole process of interdisciplinary investigation and interpretation of the resulting data has the reconstruction as a test bed: in that context, reconstructions are means to an end, not the end itself.

For reasons of clarity and emphasis, a statement on the sine qua non of the value of reconstructions as just outlined has been reserved for this concluding paragraph. The elastic term "research based" has been used throughout this contribution to describe the prerequisite for scientific validity of reconstructions. This has been a conscious choice. The determining factor has been the continuous development of research methodologies within the historically very short space of time in which sculptural polychromy has been an object of any kind of scientific investigation. All stages of development deserve recognition, on their own terms.

A point has now been reached when some ideal methodological parameters may be suggested. "Ideal" in view of the fact that the resources required in equipment and staff are all too seldom available ${ }^{56}$. Very briefly put, as in all science, cross-checks of data attained by different methods of investigation, as subsequently published, are of the essence in polychromy research. Multispectral imaging, microscopy and analyses are mainstays in an "ideal" research protocol and the validity of "research based" reconstructions will depend on data thus acquired. The availability of published supporting data will in turn refine the necessary "critical response" referred to in a general way in this contribution.

Are reconstructions an evil, albeit necessary? Potentially, yes, but no more, nor less so than is the case in our dealings with the evidence available for understanding our history: if we do not plainly inform each other and the public about in what sense the reconstruction is a means and to what end it serves, then it is an unnecessary evil.
Notes

1. I am grateful to the anonymous reviewer and the Scientific Committee for instructive and constructive comments. My special thanks go to Giovanni Verri for allowing me to reproduce his innovative process of reconstruction in figure 8 of this article.

Select bibliography on reconstructions: Brinkmann, Kellner, Koch-Brinkmann, Østergaard, 2003; Spada, 2004; Schmaltz, 2009; Brinkmann, Koch-Brinkmann, 2010; Brinkmann, Koch-Brinkmann, Piening, 2010; Piening, 2010; Jockey, Mulliez, 2012; Skovmøller, Therkildsen, 2014; Verri, Opper, Lazzarini, 2014; Brinkmann, KochBrinkmann, Piening, 2016; Zimmer, 2016; Østergaard, 2017, p. 164-166; Mulliez (ed.), 2020; Østergaard, 2019. Critical responses: Schmaltz, 2008; Mandel, 2009; Wünsche, 2011; Barry, 2011; Wünsche, 2014;

Brecoulaki, 2015; Schmaltz, 2016. An introduction to polychromy in classical sculpture: J. S. Østergaard, in Oxford Classical Dictionary, s.v. polychromy, sculptural, Greek and Roman, at https://oxfordre.com/ classics/view/10.1093/ acrefore/9780199381135.001.0001/acrefore- 9780199381135-e-8118? rskey=XYQVjd\&resu $\mathrm{lt}=1$ (consulted 27.12.2019).

2. Brinkmann, Wünsche, 2003; http:// www.stiftung-archaeologie.de/ exhibitionsen.html.

3. http://www.stiftung-archaeologie. de/reconstructionsen.html (both consulted 19.12.2019)

4. Thus, such 19th century reconstructions of great interest as JeanCharles Simart's "Athena Parthenos" (18461855 ) and John Gibson's "Tinted Venus" (1862) are not dealt with.

5. Quatremère, 1814. In references to this work, there is some confusion as to the year of publication because it was first published in 1814, and then again in 1815 . Hitherto difficult of access, Quatremères' work has happily been immediately accessible since 2005 from Paris: https:// bibliotheque-numerique.inha.fr/collection/ item/12016-le-jupiter-olympien? offset=1 (1814), and Heidelberg: https://katalog.ub. uni-heidelberg.de/cgi-bin/titel.cgi?katkey=6 $6988488 \&$ sess $=0$ fe7bd69bbeeba0a3f399a81 dcbc686e \&art $=$ f\&kat $1=$ freitext $\&$ kat $2=$ ti \& ka $\mathrm{t} 3=\mathrm{au} \& \mathrm{cop} 1=\mathrm{AND} \& \mathrm{op} 2=\mathrm{AND} \& \mathrm{var} 1=\mathrm{le} \% 20$ jupiter \% 20olympien \&var2=\&var3 = (1815) (links consulted 19.12.2019).
6. “... je l'ai fait, il faut encore le dire, plus en considération des lumières qui pouvaient en rejaillir sur le genre d'art qu'il me fallait faire connaitre, que dans la vue de reproduire les monuments pour euxmêmes." Quatremère, 1814, Avant-propos, XVIII.

7. For relevant passages, see Quatremère, 1814, xviII, XxiI, xxiv. See Henke, 2016, p. 83, 86 and passim.

8 . The format was widely used in influential publications during the 19th century for reconstructions of both sculpture and architecture, by scholars such as J. I. Hittorff, F. Kugler, G. Semper and L. Fenger. The impressive and fanciful polychrome reconstructions of ancient Greek and Roman sites by French students of the École des Beaux-Arts are not taken into consideration in this article but see

Cat. Exhib. Paris, 1982. For an overview, see Hennemeyer, 2017.

9. Furtwängler, 1906, pl. 105-106.

10. Bourgeois, Jeammet, 2018, esp. p. 153-155; Schmaltz, 2009. On the korai from the Acropolis, see K. Karakasi, Archaic Korai, Hirmer Verlag, München, 2003,

p. 115-141, pl. 125-207 and colour plates 238 278; plates 236-237 present an important 2D 
reconstruction of the Phrasikleia Kore; see also N. Kaltsas, "Die Kore und der Kouros aus Myrrhinous", in Antike Plastik 28, Gebr, Mann; Berlin 2002, p. 7-40.

11. Jones, 1854, https://archive.org/ details/anapologyforcol00jonegoog/page/ n12 (consulted 19.12.2019).

12. For the polychromy in the Greek

Court: Nichols, 2015, p. 74-77, fig. 2.4.

13. Nichols, 2015 , p. 110-111.

14. For an introduction to the site and the excavations, see Kyrieleis, 2011.

15. On Treu and the Albertinum:

Knoll, 1995, on polychromy p. 164-179;

Østergaard, 2019.

16. Treu, 1895.

17. Treu, 1884

18. Catalogue: Ausstellung farbiger und getönter Bildwerke in der königlichen National-Galerie zu Berlin vom 14 November bis 31. Dezember 1885.

19. Treu, 1884, 34: “.. das Abenteuer (i.e. of reconstructions), so gefährlich es ist, muss einmal gewagt werden, wenn unsre Vorstellungen von antiker Polychromie nicht anschauungsleeres theoretisches rede bleiben soll." Comprehensively on reconstruction ibid., p. 25-36.

20. Vierneisel, Leinz, 1980, p. 201, fig. 4. On the reconstruction: Kader, 2003 , p. 246.

21. Furtwängler, 1906, p. 299-308. Critical of Treu and Furtwängler: Gräf, 1908. The model was destroyed in World War II, but a copy of the pediment of the model is preserved in the Skulpturhalle, Basel.

22. Brinkmann, Wünsche, 2003, p. 108-

113 (V. Brinkmann).

23. See further below.

24. Furtwängler, 1906, pl. 104-105; see

Wünsche, 2014, p. 223-235.

25. Richter, 1944; Hall, 1944.

26. Blume, 2015.

27. As multi-spectral imaging, a range of microscopy techniques and analyses, allowing cross-checks.

28. On this reconstruction: M. Beard,

"Painted Cast of the Peplos Kore", in

Panzanelli, 2008, p. 126-127.

29. Inventory number $34 \mathrm{a}$ and $2 \mathrm{a}$, respectively.

30. https://www.classics.cam.ac.uk/ museum/collections/peplos-kore (consulted 19.12.2019)

Information on the present state of knowledge of the polychromy of the "Peplos Kore" will be provided in the near future (personal information from the curator in charge).

31. Boardman, 1978 , p. $80-81$ and figs. 128-129; painted photographs in figs. 131133. See also Martinez, 2000, p. 16-17, with a black and white reconstruction of the polychromy of the Lady of Auxerre and criticism of the Cambridge reconstruction. 32. Wünsche, 2011, p. 240.

33. As Brinkmann, Wünsche, 2003 , p. 103-107.

34. For critical reactions: Schmaltz, 2008, Wünsche, 2011, Wünsche, 2014. 35. Brinkmann, Wünsche, 2003; Nielsen, Østergaard, 2004; Liverani, 2004. 36 . The latest version of the exhibition:
Brinkmann, Dreyfus, Koch-Brinkmann, 2017. Phrasikleia: Brinkmann, Koch-

Brinkmann, Piening, 2010; Schmaltz, 2016 (critical). For reconstructions and publications from the Brinkmann team:

http://www.stiftung-archaeologie.de/; http://buntegoetter.liebieghaus.de/en (both consulted 19.12.2019)

37. A publication of this work is foreseen.

38. Citta del Vaticano, Musei Vaticani, inv. 36858 .

39. Liverani, 2004, p. 235-252.

40. Critical: Barry, 2011, p. 28-33.

41. Brinkmann, Wünsche, 2003, p. 43, fig. 53.

42. Brinkmann, Wünsche, 2003, p. 148

155 (R. Posamentir, U. Koch-Brinkmann). 43. Østergaard, 2003.

271

44. Østergaard, Nielsen, 2014, p. 270-

45. Skovmøller, Therkildsen, 2014.

46. Gercke, 1991; Settis, Anguissola, Gasparotto, 2015, p. 220-221. See also the reconstruction of a Roman head of a youth, Brinkmann, Wünsche, 2003, p. 132-147 (Wünsche).

47. Brinkmann, Koch-Brinkmann,

2018, with earlier bibliography.

48. Brinkmann, 2018, p. 92-115.

49. See Formigli, "Die

Oberflächengestaltung antiker

Grossbronzen”, in V. Brinkmann (ed.),

Zurück zur Klassik. Ein neuer Blick auf das alte

Griechenland. München, Hirmer, 2013,

p. 274-307, esp. p. 289-294 "Die 'natürlichen' und künstlichen Patinae”. On the polychromy of bronze sculpture, see also in this volume the essays by Descamps-Lequime and Brinkmann, Koch-Brinkmann.

50. See the many examples in

Brinkmann, 2003.

51. Verri, Opper, Lazzarini, 2014,

p. 171-177. See Brecoulaki, 2015.

52. As Blume, 2015, pl. 87, fig. 25.62.

See also Frischer, 2008 and 2013

53. Fauquet, Jockey, 2018.

54. Jockey, Mulliez, 2012

55. As in the case of the Augmented

Virtual Reality show on the Ara Pacis in

Rome: http://en.arapacis.it/mostre_ed_

eventi/eventi/1_ara_com_era (consulted

19.12.2019)

56. For a survey of methodologies, see Østergaard, 2017.

\section{Bibliography}

Barry F., 2011, "A Whiter Shade of Pale: Relative and Absolute White in Roman Sculpture and Architecture", in S. Clerbois, M. Droth (eds.), Revival and Invention: sculpture through its material histories, Peter Lang, New York, p. 31-62.

Blume C., 2015, Polychromie hellenistischer Skulptur, M. Imhof Verlag, Petersberg.

Boardman J., 1978, Greek Sculpture: The Archaic Period, Thames \& Hudson, London.

Bourgeois B., Jeammet V., 2018, "Les paradoxes de l'invention de la polychromie au XIX ${ }^{\mathrm{e}}$ siècle", in É. Papet (ed.), En couleurs. La sculpture polychrome en France 1850-1910, Éditions Hazan, p. 151-156, esp. p. 153-155.

Brecoulaki H., 2015, Bryn Mawr Classical Review 2015.10.33 at http://bmcr. brynmawr.edu/2015/2015-10-33.html last paragraphs (consulted 17.12.2019).

Brinkmann V., 2003, Die Polychromie der archaischen und frühklassischen Skulptur, Biering \& Brinkmann, München.

Brinkmann V. (ed.), 2018, Medeas Liebe und die Jagd nach dem goldenen Vlies, Hirmer, Mainz.

Brinkmann V., Dreyfus R., Koch-Brinkmann U. (eds.), 2017, Gods in Colour. Polychromy in the Ancient World, Prestel, Munich.

Brinkmann V., Kellner U., Koch-Brinkmann U., Østergaard J. S., 2003, “Die Farbfassung des Caligula-Porträts”, in Brinkmann, Wünsche, 2003, p. 206-211.

Brinkmann V., Koch-Brinkmann U., 2010, "On the Reconstruction of Antique Polychromy Techniques”, in Brinkmann, Primavesi, Hollein, 2010, p. 115-135.

Brinkmann V., Koch-Brinkmann U., 2018, "The Riace Bronzes Experiment. Aesthetics and Narrative", in M. Fuchs (ed.), Ahoros. Gedenkschrift für Hugo Meyer, Phoibos, Wien, p. 15-34.

Brinkmann V., Koch-Brinkmann U., Piening H., 2010, "The Funerary Monument to Phrasikleia”, in Brinkmann, Primavesi, Hollein, 2010, p. 188-217.

Brinkmann V., Koch-Brinkmann U., Piening H., 2016, "Die Farben der Kouroi. Erklärungen zu unserer 'generischen' Rekonstruktion”, in Zimmer, 2016, p. 71-75.

Brinkmann V., Primavesi O., Hollein M. (eds.), 2010, Circumlitio. The Polychromy of Antique and Mediaeval Sculpture, Hirmer, Mainz.

Brinkmann V., Wünsche R. (eds.), 2003, Bunte Götter. Die Farbigkeit antiker Skulptur, Hirmer, Mainz.

Cat. Exhib. Paris, 1982, Paris, Rome, Athènes. Le voyage en Grèce des architectes français aux $X I X^{e}$ et $X X^{e}$ siècles [Exhib. École nationale supérieure des Beaux-Arts, Paris, 12 mai-18 juillet 1982 , Pinacothèque nationale d'AthènesMusée Alexandre Soutzos, 15 octobre-15 décembre 1982, The Museum of Fine Arts, Houston, 17 juin-4 septembre 1983], M.-C. Hellmann, P. Fraisse, A. Jacques (eds.), École nationale supérieure des BeauxArts, Paris.

Fauquet P., Jockey Ph., 2018, "La restitution des couleurs. Des réalités antiques à l'imagerie numérique contemporaine", in Ph. Jockey (ed.), Les Arts de la couleur en Grèce ancienne... et ailleurs. Actes du Colloque international organisé à l'École francaise d'Athènes, 23-25 avril 2009 Bulletin de Correspondance Hellénique, Supplément $\mathrm{n}^{\circ}$ 56, p. 387-402.

Frischer B., 2008, "From digital illustration to digital heuristics", in B. Frischer, A. Dakouri-Hild (eds.), Beyond Illustration. 2D and 3D Digital Technologies as Tools for Discovery in Archaeology, BAR International Series 1805, BAR, Oxford 2008, p. v-XXIV. 
Frischer B., 2013, "Introduction with remarks on digital restoration of the Richmond Caligula and its methodological implications", online publication available at: http://www. digitalsculpture.org/papers/frischer/ frischer_paper.html

Furtwängler A., 1906, Ägina. Das Heiligtum der Aphaia, Franz, München.

Gercke P. (ed.), 1991, Apollon und Athena. Klassische Götterstatuen in Abgüssen und Rekonstruktionen: Katalog zur Sonderausstellung 1991, Staatliche Kunstsammlungen Kassel.

Gräf B., 1908, "Die Aufgaben einer Sammlung von Abgüssen nach antiken Skulpturen", Museumskunde 4, p. 55-65.

Hall L. F., 1944, "Notes on the Colors Preserved on the Archaic Attic Gravestones in the Metropolitan Museum", American Journal of Archaeology 48, p. $334-336$.

Henke F., 2016, "Die erste

Farbrekonstruktion der klassischen Altertumswissenschaft. Quatremère de Quincy's Zeus von Olympia", in Zimmer, 2016, p. 77-89.

Hennemeyer A., 2017, "Antike Architekturpolychromie im 19 Jahrhundert. Mit wissenschaftlicher Methode und künstlerischer Einfühlung vom Fragment zum Gesamtbild", in U. Hassler (ed.), Langfristperspektiven archäologischer Stätten. Wissensgeschichte und forschungsgeleitete Konservierung, Hirmer, Mainz, p. 275-297.

Jockey Ph., Mulliez M., 2012, "Figures et polychromie. Essai de restitution, démarche et méthode", in M. Garsson (ed.), Le trésor de Marseillais : 500 av. J.-C, l'éclat de Marseille à Delphes, Éditions Somogy, Marseille/Paris, p. 108-121.

Jones O., 1854, An Apology for the Greek Court at the Crystal Palace, London.

Kader I., 2003, “'Taüschende Spielreien'. Kolorierte Abgüsse im 19. und frühen 20. Jahrhundert", in Brinkmann, Wünsche, p. 244-255.

Knoll K., 1995, Das Albertinum vor 100 Jahren - die Skulpturensammlung Georg Treus, Staatliche Kunstsammlungen Dresden.

Kyrieleis H., 2011, Olympia. Archäologie eines Heiligtums, Philipp von Zabern, Darmstadt/Mainz.

Liverani P. (ed.), 2004, I colori del bianco. Policromia nella scultura antica, De Luca, Rome.
Liverani P., Santamaria U. (eds.), 2014, Diversamente bianco. La policromia della scultura romana, De Luca, Roma.

Mandel U., 2009, Review of Brinkmann, 2003, Klio 91, 2009, p. 252-254.

Martinez J.-L., 2000, La Dame d'Auxerre, RMN Éditions, Paris.

Mulliez M. (ed.), 2020, Reconstruction of Polychromy, Proceedings of the conference "Restituer les couleurs/Reconstruction of Polychromy ", 29 nov. 31 déc. 2017 at the Archéopôle of Bordeaux, Virtual Retrospect Meeting 2017, Éditions Ausonius, Collection Archéovision, Bordeaux

Nichols K., 2015, Greece and Rome at the Crystal Palace. Classical Sculpture and Modern Britain, 1854-1936, OUP, Oxford.

Nielsen A. M., Østergaard J. S. (eds.), 2004 ClassiColor-farven i antic skulptur. Meddelelser fra Ny Carlsberg Glyptotek, $\mathrm{Ny}$ Serie 6, Ny Carlsberg Glyptotek, Copenhagen.

Østergaard J. S., 2003, "Der Caligula in der Ny Carlsberg Glyptotek. Ein Projekt zur Rekonstruktion der polychromen Fassung eines römischen Porträts", in Wünsche, Brinkmann, 2003, p. 199-203.

Østergaard J. S., 2017, “Colour shifts. On methodologies in research on the polychromy of Greek and Roman sculpture", Proceedings of the Danish Institute at Athens 8, p. 149-176.

Østergaard J. S., 2019, "Experimental reconstructions in permanent museum displays", in Mulliez, 2020, p. 187-195.

Østergaard J. S., Nielsen A. M. (eds.), 2014, Transformations. Classical Sculpture in Colour, Ny Carlsberg Glyptotek, Copenhagen.

Panzanelli R. (ed.), 2008, The Color of Life. Polychromy in Sculpture from Antiquity to the Present, Getty Publications, Los Angeles.

Piening H., 2010, "From Scientific Findings to Reconstruction: The Technical Background to the Scientific Reconstruction of Colours", in Brinkmann, Primavesi, Hollein, 2010, p. 108-113.

Quatremère de Quincy A.-C., 1814, Le Jupiter olympien, Didot, Paris.

Richter G., 1944, "Polychromy in Greek Sculpture with Special Reference to the Archaic Attic Gravestones in the Metropolitan Museum", American Journal of Archaeology 48, p. 321-333.

Schmaltz B., 2008, "Die wundersame
Vermehrung der göttlichen Buntheit", Antike Welt, 2008/2, p. 41-44.

Schmaltz B., 2009, "Die Kore Akropolismuseum Inv. 682. Versuch einer Rekonstruktion", Jahrbuch des Deutschen Archäologischen Instituts, 124, p. 75-133.

Schmaltz B., 2016, "Neue Untersuchungen an der Statue der Phrasikleia im Athener Nationalmuseum. Es ist nicht alles Gold, was gläntz...", Jahrbuch des Deutschen Archäologischen Instituts, 131, p. 31-50.

Settis R., Anguissola A., Gasparotto D. (eds.), 2015, Serial/Portable Classic. The Greek Canon and its Mutations, Fondazione Prada.

Skovmøller A., Therkildsen R. H., 2014, "A Reconstruction. Portrait of a Young Roman Man”, in J. S. Østergaard, A. M. Nielsen (eds.), Transformations. Classical Sculpture in Colour, Ny Carlsberg Glyptotek, Copenhagen, p. 256-269.

Spada S., 2004, "Restauro e ricostruzione della policromia dell'Augusto di Prima Porta", in Liverani, 2004, p. 249-252.

Treu G., 1884, Sollen wir unsere Statuen bemalen? Berlin. https://digi.ub.uniheidelberg.de/diglit/treu1884/0038/ thumbs (consulted 19.12.2019)

Treu G., 1895, "Technik und Bemalung der olympische Giebelgruppen", Jahrbuch des Deutschen Archäologischen Instituts 10, p. 1-35.

Verri G., Opper Th., Lazzarini L., 2014, “'In picturae modum variata circumlitio'?: the reconstruction of the polychromy of a Roman female head ('Treu Head')", in Liverani, Santamaria, 2014, p. 149-183.

Vierneisel K., Leinz G. (ed.), 1980, Glyptothek München 1830-1980, München.

Wünsche R., 2011, Kampf um Troja. 200 Jahre Ägineten in München, Josef Fink, Lindenberg in Allgäu, p. 240-246, p. $249-250$, p. $256-261$

Wünsche R., 2014, "Zur Farbigkeit antiker Skulptur", in U. Hassler (ed.), Maltechnik E Farbmittel der Semperzeit, Hirmer, Munich, p. 86-96.

Zimmer K. B. (ed.), 2016, Von der Reproduktion zur Rekonstruktion - Umgang mit Antike (n) II. Summerschool vom 16.-19. Juni 2014 in Tübingen, Leidorf, Rahden/ Westf. 